\title{
COL2A1 mutation (c.3508G $>$ A) leads to avascular necrosis of the femoral head in a Chinese family: A case report
}

\author{
FANG LIU*, ZHIZHENG XIONG ${ }^{*}$, QI LIU, JINXI HU, WENHUA LI and NA ZHANG \\ Department of Orthopedics, Second Hospital of Yueyang, Yueyang, Hunan 414000, P.R. China
}

Received October 12, 2017; Accepted March 8, 2018

DOI: $10.3892 / \mathrm{mmr} .2018 .8984$

\begin{abstract}
Avascular necrosis of the femoral head (ANFH) is a consequence of ischemia. Although the majority of cases of ANFH are sporadic, certain familial cases of ANFH have been reported to be associated with collagen type II $\alpha 1$ chain (COL2A1) mutations, which lead to COL2A1 gene dysfunction. The structure of secreted type II collagen contains a core area with a triple helical glycine (Gly)-X-Y domain, and the replacement of Gly in this region as a result of COL2A1 mutations may damage the structure of type II collagen. In the present study, a Chinese family with ANFH was recruited and genetic analysis was conducted to determine whether COL2A1 mutations were implicated in this familial ANFH. A three-generation family containing 31 members, as well as 20 patients with sporadic ANFH, were recruited for investigation. The diagnosis was performed by independent surgeons and radiologists according to internationally recognized criteria. In the present study, a heterozygous c.3508G $>$ A mutation in exon 50 of the COL2A1 gene was identified, which results in the substitution of Gly with serine at codon 1,170. Furthermore, genetic pedigree analysis indicated that this mutation was inherited in an autosomal dominant manner. The present study revealed that a heterozygous c. $3508 \mathrm{G}>\mathrm{A}$ mutation in the COL2A1 gene was involved in ANFH development in one Chinese family. Therefore, it is proposed that individuals who carry this c.3508G $>$ A mutation in the COL2A1 gene should receive genetic counseling and early intervention for ANFH.
\end{abstract}

\section{Introduction}

Numerous factors, including trauma, alcohol, steroids, coagulation disorders, sickle cell disease and fat embolism,

Correspondence to: Dr Fang Liu, Department of Orthopedics, Second Hospital of Yueyang, 263 Baling Road, Yueyang, Hunan 414000, P.R. China

E-mail: liufangyyeyy@163.com

*Contributed equally

Key words: collagen type II $\alpha 1$ chain, mutation, inherited, avascular necrosis of the femoral head have been reported to be implicated in the destruction of the femoral head (1). Avascular necrosis of the femoral head $(\mathrm{ANFH})$, as a consequence of impaired blood supply, is a common type II collagenopathy that is associated with collagen type II $\alpha 1$ chain (COL2A1) mutations $(2,3)$. The primary clinical manifestations of ANFH are limping gait, discrepancy in leg length and pain on exertion, which have a substantial effect on the quality of life of individuals $(4,5)$. Although the exact pathogenesis of ANFH remains to be elucidated, evidence obtained from idiopathic osteonecrosis in twin studies indicates that genetic factors may have a vital role in the development of ANFH $(6,7)$. Additionally, genetic studies have demonstrated that various single nucleotide mutations in COL2A1 are associated with an increased risk of ANFH. Based on the data obtained from familial ANFH patients in three Chinese families, a study conducted by Liu et al (2) revealed that a $\mathrm{G}$ to $\mathrm{A}$ transition in exon 50 (c.3665G $>\mathrm{A})$ or exon 30 (c.2306G>A) in COL2A1 led to the replacement of glycine (Gly) with serine at codon 1,170 in the Gly-X-Y domain among patients with ANFH, which did not occur in healthy individuals. Furthermore, a study conducted by Li et al (8) revealed that a novel p.Gly630Ser mutation in the COL2A1 gene may have led to ANFH and Legg-Calve-Perthes disease (LCPD) in a Chinese family.

The COL2A1 gene, which is localized at 12q13, encodes the necessary element for type II collagen, characterized by three homologous $\alpha 1$-peptide chains (9). Type II collagen is predominantly expressed in the hyaline cartilage, as well as the vitreous body and nucleus pulposus (10). Type II collagen is also an essential component of collagen in the connective tissue; the biomechanical strength of this tissue is primarily dependent on the amount and extent of collagen fibril crosslinking (11). Type II collagen is composed of three homologous $\alpha 1$ peptide chains (homotrimers) that twist together to form a triple-stranded helix. The triple helical domain contains $\sim 300$ amino acids, and Gly followed by two other amino acids (AAs) constitute the repeated (Gly-X-Y) $)_{n}$ sequence. If Gly in the specific Gly-X-Y repeat is replaced by other AAs, the structure of the type II collagen is destroyed $(8,12)$. Over 200 mutations have been identified in the COL2A1 gene, and the majority of these mutations have been associated with the replacement of Gly residues in the triple helix domain (13). In recent decades, an increasing number of studies have indicated that mutations in the COL2A1 gene are associated with familial or inherited ANFH (8,14-20). However, at present, no mutation hotspot has 
been confirmed. The present study was performed to identify potential mutations in the COL2A1 gene that may be implicated in ANFH among a unique three-generation Chinese family, and to conduct a review of the literature.

\section{Case report}

Ethics statement. All experimental protocols described in the present study were approved by the Institutional Review Board of the Second Hospital of Yueyang (Yueyang, China). Written informed consent according to the Declaration of Helsinki was obtained from all subjects described in the present study.

Case presentation and pedigree analysis. A femoral head osteonecrosis pedigree with a total of 31 subjects (13 males and 18 females) of three generations (Yueyang, China) was recruited in the present study in July 2016. The proband (II-5), a male diagnosed with ANFH, visited the Second Hospital of Yueyang (Yueyang, China) in July 2014 due to groin pain and restricted motion of the left hip joint, which started when the patient was 41 years old. A comprehensive survey was conducted to obtain detailed information of the patient's medical history, physical examination and laboratory examination. Total hip replacement surgery was performed on his right hip joint in July 2014 in the Second Hospital of Yueyang. The radiograph revealed that the primary pathological change in his left hip was a flat femoral head with cystic degeneration, secondary osteoarthritis (OA) and light subluxation, indicating a Ficat stage IV lesion (21) (Fig. 1A). The patient was treated with total hip arthroplasty (Fig. 1B) and a post-operation biopsy confirmed the diagnosis.

The X-ray of the patient's spine was normal (Fig. 1C and D) and facial features were unremarkable. There were no obvious abnormalities in the patient's neurological system or limbs. A total of 11 members of the proband's family (II-1,II-8, II-9,II-10, II-12 and III-6 to III-11) had similar clinical manifestations observed in X-rays (data not shown). Due to the aggregation of similar hip disorders in this family, a pedigree analysis was conducted to determine the potential cause (Fig. 2). Subjects of the first generation had passed away.

A total of 12 family members (54.5\% of the offspring) were clinically diagnosed with ANFH (Fig. 2). Radiographic data revealed the typical features of the affected hips, including cysts, collapse, joint space narrowing, secondary OA and subluxation, indicating lesion stages ranging from Ficat II to IV. No family members had a history of trauma, alcohol, steroid use or any other high-risk factors.

Nucleic acid isolation. Blood samples of 22 family members from the same lineage as the proband and 20 sporadic ANFH volunteers were collected in July 2016 at the Second Hospital of Yueyang. Diagnois was conducted by an independent pathologist and imaging doctors. Characteristics of affected family members and sporadic ANFH volunteers are presented in Tables I and II, respectively. Genomic DNA was extracted from peripheral blood samples $(200 \mu \mathrm{l})$ using the TIANamp Blood DNA kit (Tiangen Biotech Co., Ltd., Beijing, China), according to the manufacturer's protocol, and stored at $-20^{\circ} \mathrm{C}$ prior to experimentation. The concentration and purity of the genomic DNA was measured using a NanoDrop

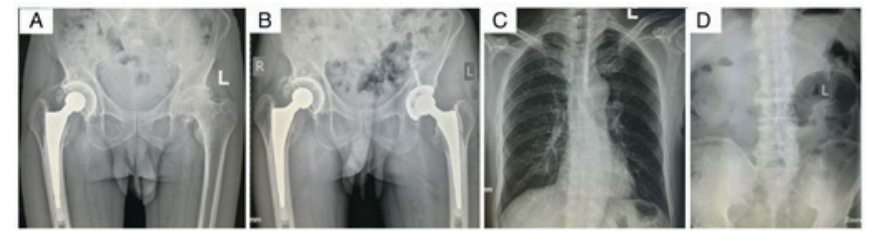

Figure 1. Radiograph of the proband, subject II-5. (A) X-ray of the proband's left hip revealed cysts, joint space narrowing and secondary osteoarthritis. (B) Total hip replacement was performed on the proband as treatment. No abnormal signs were detected on the proband's (C) thoracic vertebra and (D) lumbar vertebra. L, left; R, right.

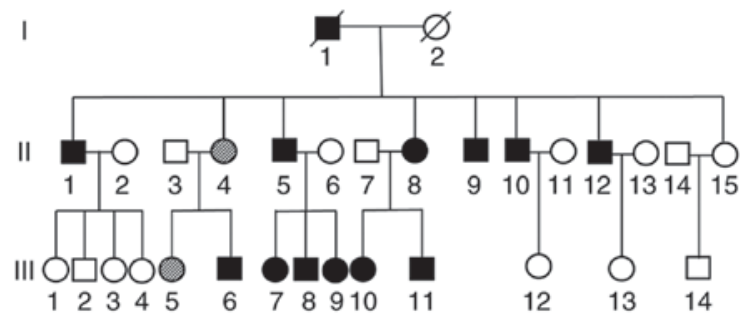

Figure 2. Pedigree analysis of the affected family. Subjects II-1, II-5, II-8, II-9, II-10, II-12 and III-6 to III-11 were diagnosed with avascular necrosis of the femoral head and a heterozygous c. $3508 \mathrm{G}>\mathrm{A}$ mutation in COL2A1 was detected in the above patients, excluding subject II-1. Subjects II-4 and III-5 were asymptomatic carriers. Subjects of the first generation had passed away. Squares represent males and circles represent females. Filled shapes represent affected family members, unfilled shapes represent unaffected family members and partially shaded shapes represent asymptomatic carriers of the c.3508G $>$ A mutation in COL2A1. Shapes with a diagonal line through them indicate deceased family members. COL2A1, collagen type II $\alpha 1$ chain.

2000 spectrophotometer (Thermo Fisher Scientific, Inc., Waltham, MA, USA) at 260/280 $\mathrm{nm}$. The process of blood sample collection and mutation detection was double-blinded. No authors had access to information that could identify individual participants during or following data collection.

COL2Al gene mutation analysis. Primers were designed based on the sequences of exon 50 in the COL2A1 gene, as previously described (9). The primer sequences were as follows: COL2A1-exon 50, TTTCCCAGCACTGATCATGG (forward) and GCCTCTCGCTGTCAGACAGA (reverse). Polymerase chain reaction (PCR) was performed using Pfu DNA Polymerase (Tiangen Biotech Co., Ltd.) in the T100 Thermal Cycler (Bio-Rad Laboratories, Inc., Hercules, CA, USA) with 100 ng genomic DNA as the template. The PCR was conducted with the following thermocycling conditions: $95^{\circ} \mathrm{C}$ for $5 \mathrm{~min}$, followed by 35 cycles of $95^{\circ} \mathrm{C}$ for $30 \mathrm{sec}, 60^{\circ} \mathrm{C}$ for $30 \mathrm{sec}$ and $72^{\circ} \mathrm{C}$ for $60 \mathrm{sec}$, and final extension at $72^{\circ} \mathrm{C}$ for $5 \mathrm{~min}$. The PCR products were subsequently sequenced by Sangon Biotech Co., Ltd (Shanghai, China). The sequencing results were compared to the National Center for Biotechnology Information reference sequence (NG_008072.1) (22) using DNAMAN 6.0 software (Lynnon LLC, San Ramon, CA, USA).

A heterozygous c.3508G $>$ A mutation within exon 50 of the COL2A1 gene was identified in the proband (Fig. 3A) and other affected members in this family, excluding subject II-1. The repeated analysis obtained the same results. Genetic analysis revealed that this mutation was inherited in an autosomal dominant manner. No mutation was found at c. $3508 \mathrm{G}>\mathrm{A}$ in 
Table I. Summary of findings of the affected members.

\begin{tabular}{|c|c|c|c|c|c|c|c|}
\hline $\begin{array}{l}\text { Family } \\
\text { members }\end{array}$ & Age & Sex & $\begin{array}{c}\text { Age at } \\
\text { onset }\end{array}$ & $\begin{array}{c}\text { Major } \\
\text { symptoms }\end{array}$ & $\begin{array}{l}\text { Radigraphic } \\
\text { findings }\end{array}$ & Genotype & Affected hip \\
\hline II 1 & 79 & $\mathrm{M}$ & 76 & Groin pain/limping & $\begin{array}{l}\text { Cystic/collapse/joint } \\
\text { space narrowing/ } \\
\text { secondary OA }\end{array}$ & Nomal & Bilateral \\
\hline II 4 & 75 & $\mathrm{~F}$ & & Asymptomatic & Normal & Mutation & \\
\hline II 5 & 71 & $\mathrm{M}$ & 60 & $\begin{array}{l}\text { Groin pain/limping/ } \\
\text { restricted motion }\end{array}$ & $\begin{array}{l}\text { Cystic /joint space } \\
\text { narrowing/secondary OA }\end{array}$ & Mutation & Bilateral \\
\hline II 8 & 68 & $\mathrm{~F}$ & 20 & Groin pain/limping & $\begin{array}{l}\text { Cystic/joint space } \\
\text { narrowing/secondary OA }\end{array}$ & Mutation & Bilateral \\
\hline II 9 & 66 & $\mathrm{M}$ & 30 & $\begin{array}{l}\text { Groin pain/limping/ } \\
\text { restricted motion }\end{array}$ & $\begin{array}{l}\text { Cystic/joint space } \\
\text { narrowing/secondary OA }\end{array}$ & Mutation & Bilateral \\
\hline II 10 & 64 & M & & Groin pain & Cystic & Mutation & Right \\
\hline II 12 & 62 & M & 30 & Groin pain/limping & $\begin{array}{l}\text { Cystic/collapse/joint } \\
\text { space narrowing }\end{array}$ & Mutation & Right \\
\hline III 5 & 58 & $\mathrm{~F}$ & & Asymptomatic & Normal & Mutation & \\
\hline III 6 & 50 & M & 49 & Groin pain & Cystic & Mutation & Right \\
\hline III 7 & 46 & $\mathrm{~F}$ & 32 & Groin pain/limping & $\begin{array}{l}\text { Cystic/collapse/joint } \\
\text { space narrowing }\end{array}$ & Mutation & Bilateral \\
\hline III 8 & 45 & M & 30 & Groin pain/limping & $\begin{array}{l}\text { Cystic/joint space } \\
\text { narrowing }\end{array}$ & Mutation & Bilateral \\
\hline III 9 & 39 & $\mathrm{~F}$ & 23 & Groin pain/limping & $\begin{array}{l}\text { Cystic/joint } \\
\text { space narrowing }\end{array}$ & Mutation & Bilateral \\
\hline III 10 & 48 & $\mathrm{~F}$ & 38 & Groin pain/limping & $\begin{array}{l}\text { Cystic/joint space } \\
\text { narrowing }\end{array}$ & Mutation & Bilateral \\
\hline III 11 & 41 & $\mathrm{M}$ & 40 & Groin pain & Normal & Mutation & Left \\
\hline
\end{tabular}

F, female; OA, osteoarthritis; M, male.

subject II-1, in which onset began at 76 years old. However, the patient received sequential bilateral total hip arthroplasty. Subjects II-2 and III-5 were also confirmed to be asymptomatic carriers and require future follow-up. The mutation described above was not detected in the other family subjects or the 20 sporadic ANFH patients (Fig. 3B).

Histology. To observe the pathological alterations, cartilage with the most severe necrosis area in the margin of the femoral head from mutant (II-5 and II-9) and control (sporadic members) groups was collected. The cartilage specimens were fixed in $10 \%$ neutral-buffered formalin overnight at $4^{\circ} \mathrm{C}$, dehydrated in an alcohol gradient, and embedded in low-melting point paraffin. Continuous $5-\mu \mathrm{m}$ thick tissue sections were cut and fixed onto silicified slides using neutral resin size at room temperature. The sections were deparaffinised and rehydrated with deionized Millipore water (EMD Millipore, Billerica, MA, USA). Sections were stained with $1 \%$ toluidine blue with borate for $20 \mathrm{~min}$ at $20-25^{\circ} \mathrm{C}$, rinsed with tap water, dehydrated, immersed in xylene for $10 \mathrm{~min}$, and then mounted with neutral resins (17).

The presence of necrotic trabeculae or newly formed trabeculae, necrotic bone marrow and fibrous tissue was observed in inherited ANFH (Fig. 4A), subject II-1 without the COL2A1 c.3508G $>$ A mutation (Fig. 4B) and sporadic ANFH
(Fig. 4C). Furthermore, empty lacunae without osteocytes were observed in both Fig. 4B and C. No marked differences were observed between inherited and sporadic ANFH.

\section{Discussion}

The present study identified a heterozygous c.3508G $>$ A mutation in the COL2A1 gene, which resulted in inherited ANFH in a large Chinese family. Unexpectedly, one family member with ANFH (II-1) had a normal genotype compared with the other affected family members; further investigation into the identification of the possible mutated genes is required. In recent decades, >200 mutations have been identified in the COL2A1 gene, including single substitution, splice-site mutations and partial deletions $(2,3,8)$. Type II collagen is a major component of the articular cartilage, which reduces articular friction and absorbs load pressure during movement. COL2A1 mutations have been associated with various human disorders, which are collectively termed type II collagenopathies and include spondyloepiphyseal dysplasia congenita, Kniest dysplasia, Stickler dysplasia, otospondylomegaepiphyseal dysplasia and spondyloepiphyseal dysplasia with premature onset arthrosis (23-26).

The c.3508G $>$ A transition identified in the present study resulted in the replacement of Gly by serine at codon 1,170 
Table II. Clinical data of 20 volunteer patients with sporadic avascular necrosis of the femoral head.

\begin{tabular}{|c|c|c|c|c|c|c|}
\hline $\begin{array}{l}\text { Sporadic } \\
\text { members }\end{array}$ & Age & Sex & $\begin{array}{l}\text { Age of } \\
\text { onset }\end{array}$ & Major symptoms & Radiographic findings & Affected hip \\
\hline 1 & 57 & $\mathrm{~F}$ & 42 & Groin pain, limping & $\begin{array}{l}\text { Cysts, collapse, joint } \\
\text { space narrowing, secondary OA }\end{array}$ & Right \\
\hline 2 & 64 & $\mathrm{~F}$ & 63 & Groin pain, limping & $\begin{array}{l}\text { Cysts, joint space narrowing, } \\
\text { secondary OA }\end{array}$ & Left \\
\hline 3 & 67 & M & 66 & $\begin{array}{l}\text { Groin pain, limping, } \\
\text { restricted motion }\end{array}$ & $\begin{array}{l}\text { Cysts, joint space narrowing, } \\
\text { secondary OA }\end{array}$ & Right \\
\hline 4 & 51 & M & 47 & Groin pain, limping & $\begin{array}{l}\text { Cysts, joint space narrowing, } \\
\text { secondary OA }\end{array}$ & Right \\
\hline 5 & 66 & M & 64 & Groin pain, limping & $\begin{array}{l}\text { Cysts, joint space narrowing, } \\
\text { collapse }\end{array}$ & Bilateral \\
\hline 6 & 85 & M & 79 & Groin pain, limping & $\begin{array}{l}\text { Cysts, joint space narrowing, } \\
\text { secondary OA }\end{array}$ & Left \\
\hline 7 & 77 & M & 67 & Groin pain, limping & $\begin{array}{l}\text { Cysts, collapse, joint space } \\
\text { narrowing }\end{array}$ & Left \\
\hline 8 & 59 & M & 55 & Groin pain, limping & $\begin{array}{l}\text { Cysts, collapse, joint space } \\
\text { narrowing }\end{array}$ & Left \\
\hline 9 & 62 & M & 52 & $\begin{array}{l}\text { Groin pain, limping, } \\
\text { restricted motion }\end{array}$ & $\begin{array}{l}\text { Cysts, collapse, joint space } \\
\text { narrowing, secondary OA }\end{array}$ & Left \\
\hline 10 & 66 & $\mathrm{~F}$ & 63 & Groin pain, limping & $\begin{array}{l}\text { Cysts, subluxation, joint } \\
\text { space narrowing }\end{array}$ & Bilateral \\
\hline 11 & 63 & $\mathrm{~F}$ & 60 & Groin pain, limping & $\begin{array}{l}\text { Cysts, joint space narrowing, } \\
\text { secondary OA }\end{array}$ & Left \\
\hline 12 & 64 & M & 62 & Groin pain, limping & Cysts, joint space narrowing & Left \\
\hline 13 & 75 & $\mathrm{~F}$ & 67 & Groin pain, limping & Cysts, joint space narrowing & Right \\
\hline 14 & 47 & M & 46 & Groin pain, limping & $\begin{array}{l}\text { Cysts, joint space narrowing, } \\
\text { secondary OA }\end{array}$ & Left \\
\hline 15 & 64 & M & 62 & Groin pain, limping & $\begin{array}{l}\text { Cysts, collapse, joint space } \\
\text { narrowing, secondary OA }\end{array}$ & Left \\
\hline 16 & 67 & $\mathrm{~F}$ & 62 & Groin pain, limping & $\begin{array}{l}\text { Cysts, collapse, joint space } \\
\text { narrowing, secondary OA }\end{array}$ & Left \\
\hline 17 & 67 & $\mathrm{~F}$ & 61 & $\begin{array}{l}\text { Groin pain, limping, } \\
\text { restricted motion }\end{array}$ & $\begin{array}{l}\text { Cysts, collapse, joint space } \\
\text { narrowing, secondary OA }\end{array}$ & Left \\
\hline 18 & 71 & M & 67 & Groin pain, limping & $\begin{array}{l}\text { Cysts, collapse, joint space } \\
\text { narrowing, secondary OA }\end{array}$ & Left \\
\hline 19 & 64 & M & 63 & $\begin{array}{l}\text { Groin pain, limping, } \\
\text { restricted motion }\end{array}$ & $\begin{array}{l}\text { Cysts, collapse, joint space } \\
\text { narrowing, secondary OA }\end{array}$ & Bilateral \\
\hline 20 & 68 & M & 62 & $\begin{array}{l}\text { Groin pain, limping, } \\
\text { restricted motion }\end{array}$ & $\begin{array}{l}\text { Cysts, collapse, joint space } \\
\text { narrowing, secondary OA }\end{array}$ & Bilateral \\
\hline
\end{tabular}

F, female; OA, osteoarthritis; M, male.

in the affected family members, leading to a hip disorder that manifested as inherited ANFH. This did not occur in control family members. Liu et al (2) revealed that a c.3665G $>$ A transition (p.G1170S) or c.2306G>A transition (p.G717S) in the COL2A1 gene led to ANFH in three Chinese families. However, the differing histopathology between inherited and sporadic ANFH and the histopathological characteristics of the mutant subjects has yet to be further discussed (2). All subjects with ANFH from the three families were confirmed to have different COL2A1 mutations. However, in the present study, no similar mutations were detected in one of the family members (subject II-1), which strongly indicates that acquired factors may have an irreversible role in the pathogenesis of ANFH. Additionally, it was reported that a c.4148G $>$ A (18) or c. $1774 \mathrm{G}>\mathrm{A}$ mutations (19) in the COL2A1 gene may also lead to familial ANFH. Notably, evidence from clinical studies has demonstrated that a single base substitution in the COL2A1 gene is also implicated in the development of LCPD $(8,14,25)$ and premature hip OA, which are two other types of type II collagenopathies $(16,27)$. However, it remains to be determined whether these diseases occur separately or simultaneously in a single family with COL2A1 mutations. 
A

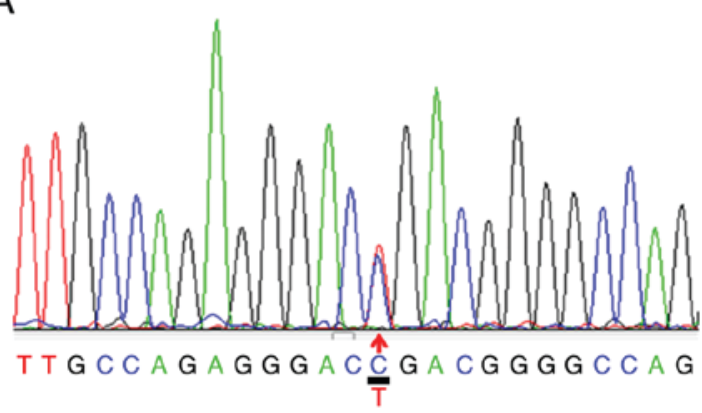

B

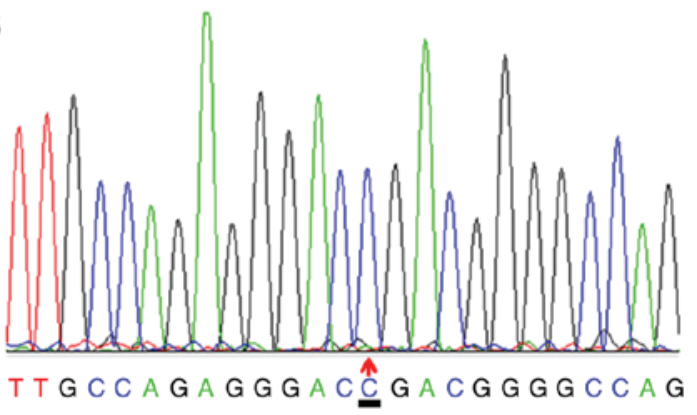

Figure 3. Sequencing analysis of COL2A1. (A) A 3508C $>$ T substitution was identified in the proband, as indicated by the arrow within the antisense strand of exon 50 in the COL2A1 gene, indicating a heterozygous c.3508G >A mutation. This mutation may result in the replacement of glycine by serine at codon 1,170 in COL2A1. This transition was also detected in other affected family members, excluding subject II-1. (B) The mutation was not detected in unaffected family members or the 20 sporadic patients. COL2A1, collagen type II $\alpha 1$ chain.
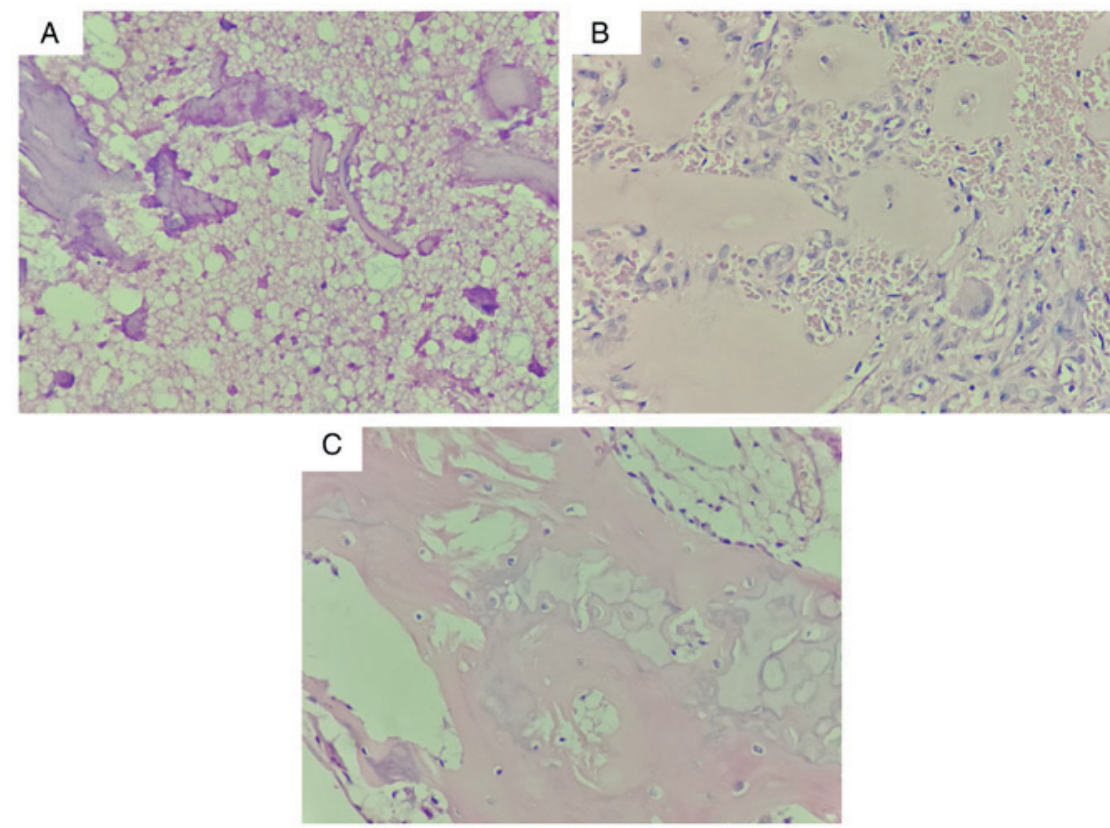

Figure 4. Histopathological analysis of femoral head cartilage by hematoxylin and eosin staining. Necrotic trabeculae (black arrows) or newly formed trabeculare (long white arrows), necrotic bone marrow and fibrous tissue (short white arrows) was observed in (A) inherited ANFH, (B) subject II-1 and (C) sporadic ANFH. Empty lacunae without osteocytes (black triangles) were observed in both subject II-1 and patients with sporadic ANFH. Subject II-1 was a family member with ANFH that did not possess the c.3508G>A mutation in collagen type II $\alpha 1$ chain that other affected family members had. No observable differences were identified between inherited and sporadic ANFH. ANFH, avascular necrosis of the femoral head. (Light microscope, magnification $\mathrm{x} 40$ ).

Although a c.3508G $>$ A transition was not reported to be associated with idiopathic osteonecrosis of the femoral head (iONFH) in sporadic Japanese patients, studies have indicated that a c.3508G $>$ A mutation may be the root cause of familial Ionfh (3). However, it remains unclear whether the $\mathrm{G}>\mathrm{A}$ transition (p.G1170S) is the hotspot mutation in COL2A1 that leads to inherited hip disorders in Chinese individuals (3). Hence, this requires further investigation.

Type II collagen is predominantly expressed in the matrix and chondrocytes. The morphology and density of chondrocytes vary according to the different depths of normal articular cartilage surface, which is divided into three zones: Superficial zone (10-20\%), middle zone (40-60\%), and deep zone (30\%) (11). One histological study revealed that the deep zone in inherited ANFH dramatically increased to $70 \%$, from $30 \%$ in normal samples, and the superficial zone dramatically decreased to $10 \%$ (17). As mature chondrocytes are primarily distributed in the superficial zone, these results indicated that the number of mature chondrocytes is significantly decreased in inherited ANFH. Furthermore, although mutated type II collagen was reported to be secreted into the matrix, the non-uniform arrangement and distribution of the pathological collagen indicated that the biomechanical characteristics of the pathological cartilage was destroyed. As endochondral ossification occurs in infant development of the femoral head, the biomechanical properties of the subchondral bone may also be markedly weakened (27). These features are notably different from sporadic ANFH, which begins with subchondral bone necrosis and does not affect the articular cartilage (28-30). No marked differences between inherited and sporadic ANFH were demonstrated in the present study. This may due to the different biopsy locations or the small sample size.

The process of type II collagen synthesis and assembly has been reported to be impaired in chondrocytes with a COL2A1 
mutation $(31,32)$. The pro- $\alpha 1$ peptide chain encoded by COL2A1 forms a triple-helix structure within the endoplasmic reticulum and Golgi bodies of chondrocytes, which integrates into numerous fibrin networks following secretion from the extracellular matrix $(10,11)$. The Gly-X-Y triple-helix motif is crucial for the proper crosslinking of the pro- $\alpha 1$ peptide chain to form functional type II collagen. The deletion of sequences for maintaining the Gly-X-Y triple-helix domain lead to type II collagenopathies $(33,34)$. Mortier et al reported that there are numerous excessive post-translational modifications in type II collagen in individuals carrying a Gly-substituted mutation (35). These excessively modified type II collagens prevent the protein from folding into its fundamental triple-helical domain structure (35). In addition, an increase in hydroxymethyl may cause local structural damage and a loosened super helix structure, resulting in pathological alterations $(8,11)$. However, why this mutation only appears to affect the hip joint remains unknown and suggests that other biomechanical factors may be involved, which require further investigation.

In conclusion, the present study identified a heterozygous c. $3508 \mathrm{G}>\mathrm{A}$ mutation in COL2A1 that was implicated in familial ANFH, and was compatible with autosomal dominant inheritance. The present study may provide a novel molecular basis for genetic counseling and the molecular diagnosis of ANFH. Further studies are required to investigate the potential mechanism underling COL2A1 mutation-induced inherited ANFH.

\section{Acknowledgements}

The authors thank Professor Xie Hui and Dr Chen Tuanhui from the Movement System Injury and Repair Research Center of Xiangya Hospital, Central South University (Changsha, China) for their methodological support with gene mutation analysis.

\section{Funding}

No funding was received.

\section{Availability of data and materials}

The datasets used and/or analyzed during the current study are available from the corresponding author on reasonable request.

\section{Authors' contributions}

FL and ZX conceived and designed the study. QL, JH and WL performed the experiments. QL, JH and NZ provided the mutants. FL and ZX wrote the paper. ZX reviewed and edited the manuscript. All authors read and approved the manuscript.

\section{Ethics approval and consent to participate}

All experimental protocols described in the present study were approved by the Institutional Review Board of the Second Hospital of Yueyang (Yueyang, China). Written informed consent was obtained from all patients, or parent, guardian or next of kin described in the present study.

\section{Consent for publication}

All the experimental protocols described in this study were approved by The Ethics Committee of Hunan Normal University (Yueyang, China). Written informed consent was obtained from all patients, or parent, guardian or next of kin for the publication of any associated data and accompanying images.

\section{Competing interests}

The authors declare that they have no competing interests.

\section{References}

1. Malizos KN, Karantanas AH, Varitimidis SE, Dailiana ZH, Bargiotas K and Maris T: Osteonecrosis of the femoral head: Etiology, imaging and treatment. Eur J Radiol 63: 16-28, 2007.

2. Liu YF, Chen WM, Lin YF, Yang RC, Lin MW, Li LH, Chang YH Jou YS, Lin PY, Su JS, et al: Type II collagen gene variants and inherited osteonecrosis of the femoral head. N Engl J Med 352: 2294-2301, 2005.

3. Sakamoto Y, Yamamoto T, Miyake N, Matsumoto N, Iida A, Nakashima Y; Research Committee on Idiopathic Osteonecrosis of the Femoral Head of the Ministry of Health, Labour and Welfare of Japan, Iwamoto Y and Ikegawa S: Screening of the COL2A1 mutation in idiopathic osteonecrosis of the femoral head. J Orthop Res 35: 768-774, 2017.

4. Zalavras CG and Lieberman JR: Osteonecrosis of the femoral head: Evaluation and treatment. J Am Acad Orthop Surg 22: 455-464, 2014.

5. Moya-Angeler J, Gianakos AL, Villa JC, Ni A and Lane JM: Current concepts on osteonecrosis of the femoral head. World J Orthop 6: 590-601, 2015.

6. Glueck CJ, Glueck HI, Welch M, Freiberg R, Tracy T, Hamer T and Stroop D: Familial idiopathic osteonecrosis mediated by familial hypofibrinolysis with high levels of plasminogen activator inhibitor. Thromb Haemost 71: 195-198, 1994.

7. Nobillot R, Le Parc JM, Benoit J and Paolaggi JB: Idiopathic osteonecrosis of the hip in twins. Ann Rheum Dis 53: 702, 1994.

8. Li N, Yu J, Cao X, Wu QY,Li WW, Li TF,Zhang C, Cui YX,Li XJ, Yin ZM and Xia XY: A Novel p.Gly630Ser mutation of COL2A1 in a Chinese family with presentations of Legg-Calvé-Perthes disease or avascular necrosis of the femoral head. PloS One 9: e100505, 2014.

9. Chen WM, Liu YF, Lin MW, Chen IC, Lin PY, Lin GL, Jou YS, Lin YT, Fann CS, Wu JY, et al: Autosomal dominant avascular necrosis of femoral head in two Taiwanese pedigrees and linkage to chromosome 12q13. Am J Hum Genet 75: 310-317, 2004.

10. Mow VC GW and Chen FH: Structure and function of articular cartilage and meniscus. Lippincott Williams and Wilkins, Philadelphia, PA, pp181-258, 2005.

11. Eyre D: Collagen of articular cartilage. Arthritis Res 4: 30-35, 2002.

12. Arnold WV and Fertala A: Skeletal diseases caused by mutations that affect collagen structure and function. Int J Biochem Cell Biol 45: 1556-1567, 2013.

13. Gelse K, Pöschl E and Aigner T: Collagens-structure, function, and biosynthesis. Adv Drug Deliv Rev 55: 1531-1546, 2003.

14. Al-Omran AK and Sadat-Ali M: Legg-Calvé-Perthes disease in two generations of male family members: A case report. J Orthop Surg (Hong Kong) 21: 258-261, 2013.

15. Kannu P, Irving $M$, Aftimos $S$ and Savarirayan R: Two novel COL2A1 mutations associated with a Legg-Calvé-Perthes disease-like presentation. Clin Orthop Relat Res 469: 1785-1790, 2011.

16. Su P, Li R, Liu S, Zhou Y, Wang X, Patil N, Mow CS, Mason JC, Huang D and Wang Y: Age at onset-dependent presentations of premature hip osteoarthritis, avascular necrosis of the femoral head, or Legg-Calvé-Perthes disease in a single family, consequent upon a p.Gly1170Ser mutation of COL2A1. Arthritis Rheum 58: 1701-1706, 2008.

17. Su P, Zhang L, Peng Y, Liang A, Du K and Huang D: A histological and ultrastructural study of femoral head cartilage in a new type II collagenopathy. Int Orthop 34: 1333-1339, 2010. 
18. Kannu P, O, Rielly DD, Hyland JC and Kokko LA: Avascular necrosis of the femoral head due to a novel $\mathrm{C}$ propeptide mutation in COL2A1. Am J Med Genet A 155A: 1759-1762, 2011.

19. Kishiya M, Nakamura Y, Ohishi H, Furukawa K and Ishibashi $Y$ : Identification of a novel COL2A1 mutation (c.1744G $>$ A) in a Japanese family: A case report. J Med Case Rep 8: 276, 2014.

20. Wang L, Pan H and Zhu ZA: A genetic pedigree analysis to identify gene mutations involved in femoral head necrosis. Mol Med Rep 10: 1835-1838, 2014.

21. Ficat RP: Idiopathic bone necrosis of the femoral head. Early diagnosis and treatment. J Bone Joint Surg Br 67: 3-9, 1985.

22. Robin NH, Moran RT and Ala-Kokko L: Homo sapiens collagen type II alpha 1 chain (COL2A1), RefSeqGene on chromosome 12 In: GeneReviews((R)). Adam MP, Ardinger HH, Pagon RA, et al (eds). University of Washington, Seattle, WA, pp 249-252, 1993.

23. Higuchi $Y$, Hasegawa $K$, Yamashita M, Tanaka $H$ and Tsukahara H: A novel mutation in the COL2A1 gene in a patient with Stickler syndrome type 1: A case report and review of the literature. J Med Case Rep 11: 237, 2017.

24. Huang X, Deng X, Xu H, Wu S, Yuan L, Yang Z, Yang Y and Deng H: Identification of a novel mutation in the COL2A1 gene in a Chinese family with spondyloepiphyseal dysplasia congenita PloS One 10: e0127529, 2015.

25. Miyamoto Y, Matsuda T, Kitoh H, Haga N, Ohashi H, Nishimura $G$ and Ikegawa $S$ : A recurrent mutation in type II collagen gene causes Legg-Calve-Perthes disease in a Japanese family. Hum Genet 121: 625-629, 2007.

26. Spranger J, Winterpacht A and Zabel B: The type II collagenopathies: A spectrum of chondrodysplasias. Eur J Pediatr 153: 56-65, 1994.

27. Kannu P, Bateman JF, Randle S, Cowie S, du Sart D, McGrath S, Edwards M and Savarirayan R: Premature arthritis is a distinct type II collagen phenotype. Arthritis Rheum 62: 1421-1430, 2010

28. Yoshida M: Experimental avascular necrosis of the femoral head-a microangiographic and histological study. Nihon Seikeigeka Gakkai Zasshi 65: 56-69, 1991 (In Japanese).

29. Mont MA, Zywiel MG, Marker DR, Mcgrath MS and Delanois RE: The natural history of untreated asymptomatic osteonecrosis of the femoral head: A systematic literature review. J Bone Joint Surg Am 92: 2165-2170, 2010.
30. Catto M: A histological study of avascular necrosis of the femoral head after transcervical fracture. J Bone Joint Surg Br 47: 749-776, 1965.

31. Bonaventure J, Cohen-Solal L, Ritvaniemi P, Van Maldergem L, Kadhom N, Delezoide AL, Maroteaux P, Prockop DJ and Ala-Kokko L: Substitution of aspartic acid for glycine at position 310 in type II collagen produces achondrogenesis II, and substitution of serine at position 805 produces hypochondrogenesis: Analysis of genotype-phenotype relationships. Biochem J 307: 823-830, 1995 .

32. Ritvaniemi P, Körkkö J, Bonaventure J, Vikkula M, Hyland J, Paassilta P, Kaitila I, Kääriäinen H, Sokolov BP and Hakala M: Identification of COL2A1 gene mutations in patients with chondrodysplasias and familial osteoarthritis. Arthritis Rheum 38: 999-1004, 1995.

33. Tiller GE, Polumbo PA, Weis MA, Bogaert R, Lachman RS, Cohn DH, Rimoin DL and Eyre DR: Dominant mutations in the type II collagen gene, COL2A1, produce spondyloepimetaphyseal dysplasia, Strudwick type. Nat Genet 11: 87-89, 1995 .

34. Tiller GE, Weis MA, Polumbo PA, Gruber HE, Rimoin DL, Cohn DH and Eyre DR: An RNA-splicing mutation (G+5IVS20) in the type II collagen gene (COL2A1) in a family with spondyloepiphyseal dysplasia congenita. Am J Hum Genet 56: 388-395, 1995.

35. Mortier GR, Weis MA, Nuytinck L, King LM, Wilkin DJ, De Paepe A, Lachman RS, Rimoin DL, Eyre DR and Cohn DH: Report of five novel and one recurrent COL2A1 mutations with analysis of genotype-phenotype correlation in patients with a lethal type II collagen disorder. J Med Genet 37: 263-271, 2000

This work is licensed under a Creative Commons Attribution-NonCommercial-NoDerivatives 4.0 International (CC BY-NC-ND 4.0) License. 